\title{
Some Fresh-Water Diatoms from Lonavla Hill-Station in the Bombay-State (Maharashtra)
}

\author{
by \\ H. P. GANDHI \\ Bahauddin College, Junagadh (Saurashtra), India \\ (with 2 plates) \\ ABSTRACT
}

In this paper the Diatomflora, based on some collections from Lonavla hill-station, is systematically accounted with some field notes.

INTRODUCTION

With the exception of a few casual remarks by the author in his earlier accounts (GANDHI, 1958, 1959a, 1959b, 1960), there exist no other records of the Diatomflora of Lonavla hill-station. It is, therefore, felt desirable to present the following notes also with a view to minimise the gaps left out while studying this flora of the whole of the South-Western zone of India, more especially of the Western Ghat ranges.

\section{LOCATION}

Lonavla is a hilly town in Maval Taluka of the District of Poona, located at $18^{\circ} 45^{\prime} \mathrm{N}$ and $70^{\circ} 24^{\prime} \mathrm{E}$, about 40 miles north-west of Poona city on Bombay-Poona line of the Central Railways. It is on the Bhore Ghat, a spur of the Western Ghat ranges. The elevation is about 2,000 feet above the mean-sea-level. It has an annual average rainfall of $166 / 200$ inches of which more than $80 \%$ is received during the season alone. The climate is typically of monsoon type and quite cool due to elevation. 
Geologically this area is called the Deccan Trap basalts. It consists of high precipitous truncated plateaus ranging in height anywhere between 1,000 to 2,000 feet above sea-level, with an occasional plain or undulating interveining terrain. Infact, this is a common feature of the entire Western Ghats. The land consists of marked horizontal volcanic lava beds of varying hardness, the more resistant and compact types are prismatic or columnar joints forming the plateau tops or vertical cliffs and the softer portions make the hilly inclines or interveining plains.

The volcanic rocks (traps) here have great thickness and form horizontal sheets. Each individual sheet varies in thickness from 40 to 100 feet, the average being 40 to 50 feet, the slope is westward. These lava beds are sometimes associated with intertrappean beds of limestone, sand-stone, clay etc.

The lava flows may commonly be found of: - the compact and harder varieties; the softer nodular flows with vesicular infillings of calcite, crystalline and amorphous quartz, zeolites (especially heulandite and stilbite); the porous ash or scoriaceous beds; the red bole bed representing altered ferruginous flows; Palagonite brown or green and intrusive acid and basic dykes, cutting across the various lava flows.

The traps usually alter into spheroidal blocks. Lateritic soil is a common decomposition product of the trap. The hill slopes are commonly characterised by loose trap boulders or soil covers causing surface creep or rock-fall during the wet season.

\section{COLLECTION}

On some botanical excursions to this place, sometimes during December 1945, February 1946 and later on in 1949 - 50 NovemberDecember, samples of algae were collected from some nallahs, water courses in hilly parts, borders of a rivulet and miscellaneous pools so commonly met with around the hilly terrain. The samples were on the spot preserved in 5\% commercial formalin and later on studied systematically in parts at different times (1946-48, 1952-56 and 1958), the result of which is indicated in the following pages.

In this account all those diatoms are described which appear to be new records for India and the new taxa, while other species found are merely listed. It would be fair to point out here that this account is by no means complete in as much as it is based on a comparatively small number of samples derived from a few localities. It would 
be, therefore, of advantage for any future worker to study this flora more completely and expeditiously to elucidate any specific views. This account is more or less a casual survey and frame-work for a more comprehensive study and if it could be of any guidance to any future worker in any particular direction, that is all is intended.

\section{SYSTEMATIC ENUMERATION}

\section{Melosira granulata (EHR.) RALFS}

This diatom was found usually in small number in brownish detritus lying on the borders of large pools or slowly flowing water courses.

\section{Melosira granulata v. angustissima MüLL.}

This diatom was found more frequently than the above type in samples derived from streams, slowly flowing water courses, wet soil around taps etc. Sometimes it was found in masses in pale brown matter lying in stagnant pools formed under taps.

\section{Cyclotella meneghiniana KüTz.}

This species occurred in practically all the samples derived from stagnant pools, puddles, ditches, waste-water courses and the like but in small number or as a stray diatom. It was never recorded from hill streams or water veins oozing from the rocky cliffs.

\section{Cyclotella glomerata BACHMANN}

This diatom was found to be widely distributed in the region. It occurred in gregarious formations in hill-streams, water courses, borders of certain pools formed along the railway tract etc. It usually occurred in light brown powdery matter.

\section{Fragilaria ungeriana GRUN. (P1. 1, figs. 1-2)}

Cholnoky, 1956, Öster. bot. Z., 103: 71, t. 3, f. 62-67; 1957, ibid., 104: 53, t. 3, f. 89-94; 1958, Senck. Biol., 39 (5-6): 319, f. 4-5; 1958b, Port. Acta biol. (B), 6 (2): 116, t. 4, f. 82; 1960, Nova Hedwigia, 2 (1-2): 44, t. 3, f. 137; SchmIDT, 1874-1960, Atlas Diat., t. 305, f. 10-17 (= Synedra dorsiventralis O. MüLL.); RICH, 1936, Trans. roy. Soc. S. Afr., 24: 207, f, 8 A-B (= S. dorsiventralis v. angusta RICH); Venkatraman, 1939, Proc. Indian Acad. Sci. B, 10: 304, f. 27, 42 (= Fragilaria intermedia GRUN. v. robusta VENKAT.); GaNDHI, 1957, Ceylon F. Sci. (Biol. Sci.), 1 (1): 46, pl. 13, f. 1 (=F. intermedia GRUN.).

Frustules formed in broad chains or ribbons. Valves $62.5-74 \mu$ long (rarely upto $100 \mu$ ) and 8.7-9 $\mu$ broad, linear to somewhat 
lanceolate with constricted, rostrate to somewhat capitate rounded ends. Pseudoraphe narrow and linear with mucilage pore at terminal nodules. Central area very variable, unilateral to bilateral sometimes with faint interrupted or incompletely formed striae, mucilage pore unilateral. Striae very coarse, $9-10$ in $10 \mu$.

This species was found widely distributed in the area. Practically all the algal samples yielded it at least in smaller numbers, sometimes it was gregarious in masses of vegetable detritus. It was more commonly seen in large pools or ponds.

Here, the author has to reconsider the identity of his $F$. intermedia GRUN. or $F$. intermedia v. robusta VENRAT., in the light of greater information available to him now. CHOLNOKY, of late, by his continued, precise and critical observations has clearly brought into relief that Fragilaria ungeriana GRUN. is a species capable of exhibiting a wide range of variations. Its shape varies from linear to lanceolate; apices cuneate, apiculate, rostrate, subcapitate to capitate; central area longitudinally elliptical, unilaterally widened, bilaterally widened, with or without incompletely formed striae and sometimes the middle part is somewhat bulged. Central area with a mucilage pore unilaterally situated. All these features have been well depicted by CHOLNOKY in his excellent illustrations. The present author also found in his forms most of these features, he is therefore impelled to refer his specimens, also his previously recorded ones, to $F$. ungeriana GRUN., also for another reason that this species previously had been reported from Belgaum in South India by KITTON in early 1884 (HustedT, 1949-50, Hydrobiol., 2: 47). The illustrations of $F$. ungeriana depicted in the "Atlas Diat. t. 298, f. 1-8", also compare well here with the exception of the apices.

6. Synedra ulna (NITz.) EHR.

This is a common diatom found practically in all the collections. Occasionally it was gregarious particularly in larger bodies of water.

7. Eunotia pectinalis (KÜTZ.) RABH. v. minor (KÜTZ.) RABH. f. impressa (EHR.) Hust. (Pl. 1, fig. 3)

HustedT, 1930, Bacil., 182, f. 239; 1930-1960, Rabenhorst's Kryptogamenfl., II, 7: 298, f. 763 g-h; Cleve-Euler, 1953, Diat. Schwed. Finn. - II, 84, f. 409 g-h.

Valves $35-43.7 \mu$ long and $6-8 \mu$ broad, arcuate, linear, dorsal side convex but straight and slightly depressed in the middle; ventral side slightly concave, ends somewhat abruptly narrowed on the dorsal side, broadly produced, subcapitate and rounded. Polar nodules small but distinct. Striae $12-14$ in $10 \mu$, well marked, somewhat irregularly disposed in the middle zone. 
This diatom was found mostly as a stray specimen in samples collected from stagnant pools and ditches. Good number of specimens were seen in a sample derived from a large ditch in bed of the rivulet.

\section{Cocconeis placentula EHR.}

This species was collected from several pools, puddles and water courses having plenty of vegetable detritus. It occurred mostly in pale brownish matter. Less common.

9. Cocconeis placentula v. euglypta (EHR.) CL.

This diatom was found to be a common type well distributed over the entire region. It occurred more frequently than the above type mixed up in vegetable detritus.

10. Achnanthes microcephala KüTz.

This species was recorded in good number from various stagnant pools, clusters of wet mosses and hill streams.

11. Achnanthes affinis GruN.

This species also occurred in good number in samples collected from pools, puddles and other bodies of stagnant water. It often associated with the above type.

12. Achnanthes hungarica GRUN.

This diatom was collected in small number from a pool under a tap and some other small bodies of water in the vicinity of the railway station.

\section{Achnanthes exigua GRUN.}

This diatom was found in varying numbers in samples collected from pools, puddles, ditches and streams. It mostly occurred in brownish masses of matter loosely lying around the wet situation. It is a common type.

\section{Achnanthes exigua v. heterovalvata KRASSKE}

This diatom was found associated with the above named species but usually in very small numbers. In most samples it occurred as a stray specimen.

\section{Achnanthes lanceolata BRÉB.}

This species was found in good number in samples collected mostly from clusters of wet mosses bordering the hill streams or water veins seeping out from the rocky cliffs. In certain reservoirs it occurred in encrustations. Fairly common. 


\section{Frustulia saxonica RABH.}

This species was commonly found embedded in slimy pale brownish matter in various hill streams, pools formed under the leaky pipe line and some pools in the rivulet.

\section{Frustulia vulgaris THw.}

This species was usually found in small numbers in samples derived from hill streams and pools therein.

18. Frustulia vulgaris v. subcapitata GANDHI (P1. 2, fig. 30)

GANDHI, 1959, Hydrobiol., 14 (2): 103, pl. 1, f. 28-29.

Valves $33.7-35 \mu$ long and $10.8 \mu$ broad, striae 24 in the middle to 28 in $10 \mu$ at the ends, finely punctate.

This diatom was found in usually smaller numbers along with the type. The forms recorded from this area seem to be comparatively broader than those recorded from Panhalgarh hill-fort.

19. Caloneis pulchra MessiK. (Pl. 1. fig. 4)

Hustedt, 1930, Bacil., 235, f. 357; Cleve-Euler, 1955, Diat. Schwed. Finn. - IV, 106, f. 1152 a-d (= v. genuina A. CL.).

Valves $43-57 \mu$ long and $6 / 7-8.7 \mu$ broad, linear with an evident inflation in the middle, ends broadly rounded. Raphe thin and straight, central pores distinct and somewhat distantly set and terminal fissures slightly curved. Axial area fairly wide linearlanceolate; central area quite wide and longitudinally elliptical. Striae about $20-21$ in $10 \mu$, radial throughout but less so towards the ends or tending to be perpendicular to the middle line, crossed by a faint fine line near the margin.

This species was found usually in small number from pools and streams. It also occurred in clusters of wet mosses and liverworts on the hilly inclines. Fairly distributed in the area.

This diatom agrees well with that of HusteDT's but sometimes somewhat larger specimens were also recorded.

20. Caloneis bacillum (GRUN.) MERESCH. (P1. 1, figs. 5-6)

Hustedt, 1930, Bacil., 236, f. 360.

Valves $23.7-32 \mu$ long and 5.8-6.5 $\mu$ broad, striae 20 to 24 in $10 \mu$.

This species occurred as a common form in most of the collections but it was more frequently noted in samples collected from borders of large bodies of water. The individual specimens seem to vary much in their shape and length to breadth proportions. The cells appear to be more slimmer than those recorded from other areas. 
21. Caloneis silicula (EHR.) CL.

This diatom was mostly recorded in small number in samples collected from streams, pools, ditches and other bodies of water. It never occurred in any quantity although all samples contained it sometimes even as a stray specimen.

22. Caloneis silicula v. minuta GRUN. (Pl. 1, fig. 7)

HusTed, 1911, Abh. naturw. Ver. Bremen, 20: 282, pl. 2, f. 26; Cleve-Euler, 1955, Diat. Schwed. Finn. - IV, 100, f. 1144 m-n (=C. silicula s. sp. ventricosa (DoNK. erw.) MAYER v. minuta (Grun.) MAYER); VAN Heurck, 1896, Treat. Diat., 220, pl. 5, f. 210 (= Navicula ventricosa (EHR.) DoNK. v. minuta V. H.).

Valves $18-20.5 \mu$ long and $5.5 \mu$ broad, linear with slightly triundulate sides and subcuneate somewhat beaklike ends. Raphe thin and straight, central pores somewhat approximate, terminal fissures weakly curved. Axial area linear-lanceolate; central area subrectangular reaching the sides. Striae about 22 in $10 \mu$, slightly radial and distinct.

This diatom was mostly found in very small number or as a stray form. It occurred in samples collected from hill streams and some pools in the bed of the rivulet. A few specimens also were recorded in collections from clusters of wet mosses.

\section{Neidium dubium (EHR.) CL. v. cuneatum FonT. (P1. 1, fig. 8)}

Cleve-Euler, 1955, Diat. Schwed. Finn. - IV, 117, f. 1170 i-l.

Valves $36.2-38 \mu$ long and $11.2 \mu$ broad, linear with broadly cuneate rounded ends. Raphe thin and straight, indistinctly oblique with central pores very shortly bent in the contrary directions and terminal fissures shortly bifurcated. Axial area very narrow, linear; central area small elliptical or roundish. Striae $17-18$ in $10 \mu$, fine but clearly punctate, slightly radial, crossed by primary furrow close to the margin but distinct than the closeby secondary furrow.

This diatom was collected from slowly flowing water courses and some stray pools. It mostly occurred as a stray form.

\section{Neidium capitellata GANDHI (P1. 2, fig. 31)}

This diatom was found in a few samples collected from pools in the rivulet and clusters of wet mosses on hill inclines. Sparsely distributed in the area.

25. Diploneis ovalis (HILSE) CL. v. oblongella (NAEG.) CL. (P1. 1, fig. 9) HustedT, 1930, Bacil., 249, f. 391; - 1930-1960, Rabenhorst's Kryptogamenfl., II, 7 : 672, f. 1065 f-k; Cleve-Euler, 1953, Diat. Schwed. Finn. - III, 76, f. 644 a (=D. oblongella (NAEG.) CL. v. genuina A. CL.). 
Valves $19-24 \mu$ long and $7.5-8 \mu$ broad, oblong-elliptical or linear with broadly rounded ends. Raphe thin and straight between the siliceous ribs, horns slightly dilated in central nodule. Axial area very narrow; central area small and roundish, furrows narrowly lanceolate, somewhat widened in the middle. Costae about 14-16 in $10 \mu$, fine and radial, alternating with one row of fine punctae or alveoli.

This diatom was found in large number in several pools forming encrustations on partially submerged rocks, in moss and liverwort clusters formed along water veins on hill inclines, waste water courses etc. It appeared to be a common diatom in the locality.

26. Diploneis puella (Schum.) CI.

This diatom was found practically in all the samples collected from the region but it appeared in small number or as a stray form.

\section{Diploneis subovalis $\mathrm{CL}$.}

This species was found mostly in samples collected from large pools, water courses, clusters of wet mosses and puddles formed under leaky pipe line. It occurred in small number or as a stray form.

\section{Stauroneis phoenicenteron EHR.}

This diatom was frequently found in samples collected from water courses, hill streams, large pools in the rivulet mixed up with pale brown deposits. However, it was never noted in gregarious formation. A common type.

\section{Stauroneis phoenicenteron f. producta GANDHI}

This diatom was more common in samples collected from various water courses and pools in the rivulet. It occurred in pale brown encrustations or as deposition on submerged leaves.

\section{Stauroneis anceps EHR.}

This species was found in several samples collected from various bodies of water, in smaller or larger numbers. It was more frequent in slowly flowing water courses.

\section{Navicula cuspidata KüTZ.}

This species was collected mostly from larger bodies of water lying there in with dead masses of vegetable matter. Stray specimens also were recorded in samples derived from pools in the rivulet. Not common in the area.

32. Navicula cuspidata v. ambigua (EHR.) CL.

This diatom was found to be more wide spread in the region since 
many samples contained it in smaller or larger numbers. More commonly found in large pools.

33. Navicula cuspidata v. brevirostrata GaNDHI (P1. 1, fig. 10)

GaNDHI, 1958, F. Bombay Nat. Hist. Soc., 55 : 496, f. 36.

Valves $60-76 \mu$ long and $20-22 \mu$ broad, striae: transverse 16 in $10 \mu$, longitudinal $25-26$ in $10 \mu$.

This diatom was collected in small number from borders of large pools and some water courses, stagnant pools in the rivulet etc. However, it did not occur in appreciable number at any time.

The forms recorded from the present locality, some were found larger than those of Kolhapur and tended to show more lanceolate shape, of course, with shortly rostrate apices.

\section{Navicula disjuncta HustedT (P1. 1, fig. 11)}

Schmidt, 1874-1960, Atlas Diat., t. 370, f. 45; Hustedt, 1930, Bacil., 274, f. 451; - 1954, Arch. Hydrobiol., 48 (4) : 471, f. 57; FoGED, 1959, Biol. Skrift., 11 (1): 53, pl. 3, f. 8.

Valves $22-26 \mu$ long and $4.8-5.4 \mu$ broad, linear-lanceolate, slightly convex in the middle with constricted broadly capitate rounded ends. Raphe thin and straight with terminal fissures slightly curved at extreme ends. Axial area very narrow throughout; central area very wide somewhat rectangular. Striae about $25-26$ in $10 \mu$, fairly radial throughout, middle striae very much shortened.

This species was found in samples collected from hill streams and water veins running down from hilly inclines. It occurred in pale brownish films formed on the margins and with mosses. Stray specimens also were found in slowly flowing water courses.

\section{Navicula mutica KüTZ.}

It was found to be a common diatom in samples collected from borders of pools, puddles and ditches. It was found to be more common on wet soils under the taps and leaky pipe line.

\section{Navicula mutica v. cohnii (HILsE) GRUN. (P1. 1, fig. 12)}

MaYer, 1917, Denkschr. Kgl. Bay. Bot. Ges. Regen., 13: 31, t. 3, f. 8a-b; Hustedt, 1930, Bacil., 275, f. 453b; Lund, 1946, New Phytol., 45 (1): 71, f. 6 E, H.; Cleve-Euler, 1954, Diat. Schwed. Finn. - III, 193, f. 907 e (= v. elliptica A. CL.).

Valves broadly elliptical, small, $11-15 \mu$ long and 7-7.4 $\mu$ broad without constricted apices. Raphe thin and straight with central pores slightly unilaterally inclined and terminal fissures slightly curved. Axial area narrow, linear-lanceolate; central area quite large with a coarse stigma placed on one side. Striae $12-14$ in $10 \mu$, 
coarsely punctate and radial throughout, end striae somewhat closely set.

This diatom was collected from miscellaneous pools and ditches. Stray specimens also were recorded from hill streams and wet clusters of mosses. It occurred mostly in small number associated or not with the above type.

\section{Navicula pupula KüTz.}

This appeared to be a common diatom in several localities mostly found in the marginal slime of the wet body. A widely distributed species.

\section{Navicula pupula v. rectangularis (GREG.) GRUN.}

This diatom usually associated with the above species and was recorded in small number.

\section{Navicula pupula v. capitata HusTEDT}

This type also associated with the above diatoms and was somewhat more frequent in samples derived from pools and ditches.

40. Navicula pupula v. elliptica Hustedt (P1. 1, fig. 13)

This diatom was found to be more wide spread in the locality though it did not appear in large numbers. Apices of some of the forms were found to be slightly constricted unlike in forms recorded from other regions.

41. Navicula subhamulata GRUN. (Pl. 1, fig. 14)

Hustedt, 1930, Bacil., 282, f. 468a; Schmidt, 1874-1960, Atlas Diat., t. 403, f. 16-18; Cleve-Euler, 1954, Diat. Schwed. Finn. III, 184, f. 889A; Cholnoky, 1960, Nova Hedwigia, 2 (1-2): 81, t. 7, f. 249.

Valves $16-22 \mu$ long and 5.6-7.2 $\mu$ broad, linear-elliptical with broadly rounded ends. Raphe thin and straight with central pores very apparent surrounded by $\mathrm{H}$-shaped very small clear zone in the central nodule, terminal fissures slightly but clearly curved. Axial area very narrow, linear; central area extremely small. Striae about 27 in $10 \mu$ rarely upto 30 , rather fine, weakly radial throughout by inner half faint.

This diatom appeared in fair number in samples collected from hill streams, slowly flowing water courses and in pools of the rivulet. It occurred in slimy matter loosely lying on submerged objects. Stray specimens also were found in puddles formed under the leaky pipe line.

42. Navicula terrestris Boye PET. (P1. 1, fig. 15)

Lund, 1946, New Phytol., 45 (1): 80-83, f. 7 M-T; Cholnoky, 
1960, Nova Hedwigia, 2 (1-2): 84; HustedT, 1930, Bacil., 285, f. 477 (= Nav. gibbula CL.); - 1957, Abh. naturw. Ver. Bremen, 34: $285(=N$. gibbula $)$.

Valves $24-36 \mu$ long and $8-8.7 / 9 \mu$ broad, lanceolate-elliptical to linear elliptical with unconstricted subcuneately rounded ends. Raphe thin and straight with central pores or fissures sharply unilaterally reflexed almost at right angles to the longitudinal line; terminal fissures slightly bent at the extreme ends. Axial area very narrow; central area longitudinally elliptical and small. Striae $14-16$ in the middle to about 20 in $10 \mu$ towards the ends, fine but clearly punctate, radial throughout and crossed by longitudinal line or space close to the raphe, axial row of punctae of the striae more clearer than the rest.

This species was found in several samples collected from pools, puddles, water courses, streams, wet mosses etc., but it usually occurred in small numbers.

This species had been a subject of very critical study and well deserved discussion led by LUND who, as the author thinks, rightly separated it from N. gibbula Cl. (CLEve, 1894, K. Sv. Vet.-Akad. Handl., 26: 140, t. 5, f. 17) and also considered HusTEDT's N. gibbula Cl., to be $N$. terrestris BoYe Pet. From ClevE's illustration of $N$. gibbula, it is quite evident that the species observed by HusteDT is quite different. HusTEDT, however, in his later works considered his type as well as $N$. terrestris of PETERSEN to be $N$. gibbula (Hustedt, 1957, Abh. naturw. Ver. Bremen, 34: 285), despite of LuND's remarks. He supported his views with the remark that he had examined the original preparations of LÖTSCHER and LAGERSTEDT but - CLEVE's original preparations are not at all being referred to as it appears from his statement.

Again, CHOLNOKY observed a similar type (like the present one) and considered it to be $N$. terrestris, lending support to LuND's observations and statements. The present author is also inclined to accept the views held by LuND and CHOLNOKY, of course with one drawback that he has no access to CIEVE's original material or the type slide of his species and perhaps the same difficulty appears to have been experienced by above named workers.

43. Navicula lucidula Grun. (P1. 1, fig. 16)

Hustedt, 1930, Bacil., 288, f. 486; CleVE-Euler, 1954, Diat. Schwed. Finn. - III, 164, f. 832 (= f. typica A. CL.).

Valves $14-17 \mu$ long and $7.5-8.5 \mu$ broad, broadly elliptical with unconstricted broadly rounded ends. Raphe thin and straight with terminal fissures slightly curved. Axial area very narrow, linear; central area slightly formed. Striae $16-17$ in $10 \mu$, clearly punctate, 
punctae about 17 in $10 \mu$, arranged in straight longitudinal rows, striae radial throughout.

This diatom was found in good number in many samples collected from the water courses, pools in the rivulet, wet mosses growing along water veins from hill inclines. Stray specimens also were observed in samples derived from puddles formed under leaky pipes. A fairly common diatom in the locality.

\section{Navicula cryptocephala KüTz.}

A widely distributed diatom in the area but more commonly found in samples from pools and large ditches.

45. Navicula rhynchocephala KüTz. v. amphiceros V. H. (P1. 1, fig. 17)

This diatom also was recorded from several pools and other bodies of water but usually in small numbers.

46. Navicula avenacea BRÉB. (P1. 1, fig. 18)

Frenguelit, 1923, Bol. Acad. Cienc. Cordoba, 27: 49, t. 4, f. 12; Cleve-Euler, 1954, Diat. Schwed. Finn. - III, 151, f. 807; Hustedt, 1930, Bacil., 297 (= N. viridula KüTz. v. avenacea (BRÉB.) GRUN.).

Valves $47-5.1 \mu$ long and $9.8 \mu$ broad, narrowly lanceolate with slightly constricted, produced, bluntly rounded ends. Raphe thin and straight with central pores somewhat closely set and terminal fissures curved. Axial area narrow, linear; central area quite large transversely elliptical. Striae about $9-10$ in $10 \mu$, clearly lineate, radial in the middle and convergent at the ends where they are somewhat closely set, about 13 in $10 \mu$.

This diatom was found in several samples collected from pools in the rivulet, water courses, and other somewhat polluted bodies of water. It occurred in association of above named species.

47. Navicula cari EHR. v. angusta GRUN.

This diatom was quite frequently observed in several samples but in good numbers it was seen in samples collected from hill streams and wet moss clusters.

48. Navicula radiosa KüTz. (Pl. 1, fig. 19)

This diatom mostly occured in small number in most of the samples from pools etc.

49. Navicula gracilis EHR. (Pl. 1, fig. 20)

MAYER, 1919, Kryptog. Forsch., 1 (4): 203, t. 3, f. 49; HustedT, 1930, Bacil., 299, f. 514; Cleve-Euler, 1954, Diat. Schwed. Finn. III, 130, f. 756a-d. 
Valves 52-60 $\mu$ long and 9-11 $\mu$ broad, narrowly lanceolate with unconstricted acutely rounded ends. Raphe thin and straight with slightly curved terminal fissures. Axial area quite narrow and linear; central area fairly enlarged, somewhat rectangular. Striae about $10-12$ in $10 \mu$, slightly radial and parallel in the middle and almost perpendicular at length and a few weakly convergent at the extreme ends, middle striae (2-3) much shortened.

This species was found normally in good number in samples collected from pools in the rivulet, stagnant water courses, puddles formed under the leaky pipes, and the like. A common diatom in the area.

The specimens recorded from this area mostly showed narrowly lanceolate shape and only very stray specimen were with slightly linear outline as illustrated by CLEVE-EuLER. The present form fully compares with MAYER's and to some extent with that of HUSTEDT.

50. Navicula andium FRENGUELli (PI. 2, fig. 32)

FreNGUELli, 1942, Rev. Museo La Plata, 5: 123, t. 2, f. 7.

Valves $66-78 \mu$ long and $10-12.5 \mu$ broad, narrowly lanceolate with unconstricted rounded ends. Raphe thin and straight with central pores slightly distantly placed and terminal fissures curved. Axial area fairly wide, narrowly lanceolate; central area not quite distinct. Striae about $10-12$ in $10 \mu$, quite radial in the middle and slightly convergent at extreme ends, faintly lineate.

This species was found in samples collected from pools in the rivulet, water courses around the hills, water veins on hill inclines etc. It occurred in good number in some of the samples only.

This diatom compares quite well with FRENGUELLI's type but specimens recorded from this locality were found to be less broad. Husted also has described somewhat similar looking forms as $N$. concamerata Hust. (HustedT, 1937-38, Arch. Hydrobiol., Suppl., 15: 280, t. 19, f. 5-6; SchmIDT, 1874-1960, Atlas Diat., t. 405, f. 1-3), but they seem to have somewhat lanceolate-rhomboid shape, smaller dimensions and the raphe having closely placed central pores, thus they differ from the present specimens.

51. Navicula constans Hust. v. symmetrica Hust. (P1. 1, fig. 21)

Hustedt, 1957, Abh. naturw. Ver. Bremen, 34 (3): 289, f. 40-41.

Valves $23.7-27 \mu$ long and 9-12 $\mu$ broad, elliptical-lanceolate with constricted, broadly subcapitate rounded ends. Raphe thin and straight with terminal fissures slightly curved. Axial area very narrow; central area fairly wide somewhat quadrate without any stigma. Striae about 14 in the middle and upto 18 in $10 \mu$ at the ends, radial throughout, some of the middle striae irregularly shortened also they become gradually closely set towards the apices. 
This species was fairly frequent in samples collected from slowly flowing water courses, hill streams, pools in the rivulet and in clusters of wet mosses along the water veins from hill inclines.

52. Navicula dicephala (EHR.) W. SMITH v. sphaerophora A. CL.

This diatom occurred in good number from cluster of wet mosses and liverworts growing along the water veins from hill inclines. It also occurred in small number in samples collected from pools in the rivulet. Not quite common in the area.

53. Navicula laterostrata HustedT (P1. 1, fig. 22)

Hustedt, 1925, Int. Rev. Ges. Hydrobiol. Hydrogr., 13: 357, f. 4; 1930, Bacil., 301, f. 521; Fukushima, 1954, Sci. Res. Ozegahara Moor, 1954: 612, f. 4 g.

Valves $19-22 \mu$ long and $7.8-8 \mu$ broad, elliptical-lanceolate with slightly constricted, broadly produced rounded ends. Raphe thin and straight with central pores slightly distantly set and terminal fissures slightly curved. Axial area quite narrow, linear; central area fairly large, roundish-elliptical. Striae $15-16$ in the middle to $20-22$ in $10 \mu$, towards the ends, gradually becoming closely set, throughout radial but less so towards ends, some of the middle striae alternate with shorter ones.

This species was commonly seen in collections made from pools in the rivulet, hill streams, puddles formed under the taps and the pipe line. It occurred mostly in brownish matrix collected around the wet bodies of water. Not quite common in the area.

54. Pinnularia interrupta W. $\mathrm{S}_{M}$.

This diatom appeared in many samples but mostly in small number. A common type in the locality.

\section{Pinnularia braunii (GRUN.) Cleve}

This species was seen usually in small number in samples collected from water courses.

56. Pinnularia lonavlensis sp. nov. (PI. 1, fig. 23)

Valvae $31.2-34 \mu$ longae atque $7.5 \mu$ latae (in medio solus $7 \mu$ ), lineares, aliquantum concavae in parte media, apicibus constrictis, late productis vel paululum capitatis et rotundatis. Raphe tenuis et recta, poris centralibus conspicua et unilateraliter inclinatis, fissuris terminalibus clare curvatis. Area axialis fere lata linearis; area centralis lata rectangularis ad margines perveniens. Striae circiter 13-16 in $10 \mu$, paululum radiales in medio, parallelis ac paululum convergentes ad apices. Typus lectus a H. P. GANDHI ad Lonavla dei 
Januari 1946, et positus in herbario proprio auctoris sub numero slide LON-7: 208.

Valves $31.2-34 \mu$ long and $7.5 \mu$ broad (in the middle only $7 \mu$ ), linear, slightly concave in the middle part, ends slightly constricted, broadly produced to slightly capitate and rounded. Raphe thin and straight, central pores conspicuous and unilaterally bent, terminal fissures clearly curved. Axial area fairly wide, linear; central area broadly rectangular reaching the sides. Striae about $13-16$ in $10 \mu$, very slightly radial in the middle, parallel and slightly convergent at the ends.

This diatom was found in samples collected from pools in the rivulet and some water courses in the hilly region. It usually occurred in small number. Not quite common in the area.

This diatom does not compare well with any known types hence it is considered as a new species.

57. Pinnularia eburnea (CARLson) Zanon (P1. 1, fig. 24)

CholNoky, 1959, Österr. bot. Z., 106: 62, f. 331; - 1960, Nova Hedwigia, 2 (1-2): 108, t. 9, f. 324-331; Zanon, 1941, Pont. Akad. Sci. Comment., 5: 49, t. 3, f. 16-18 (= P. eburnea ZaNON).

Valves $46-56.8 \mu$ long and $9-11.2 \mu$ broad, linear with broadly cuneate subtruncate ends but not at all produced or constricted. Raphe thin slightly bent with conspicuous central pores unilaterally inclined and terminal fissures deeply curved and reflexed. Axial area linear; central area fairly wide roundish to roundish-quadrate. Striae very thick $4-5$ in $10 \mu$, slightly radial in the middle and convergent at the ends, space in between the costae is almost as thick as the striae.

This species was collected usually in small number or as stray specimens from pools in the rivulet and some water courses around the hills. Not common in the area.

This species has been well considered by CHOLNOKY during recent times. He, by his continued collection work and devoted study of the African material, has been able to suggest that this species is capable of exhibiting a good deal of form change as is being evidenced by his excellent illustrations. Some of the phases of this species even perhaps tend to compare with some forms of $P$. borealis EHR.

While referring to ZaNON's $P$. eburnea ZANON, which CHOLNOKY considered to be identical with his forms, the illustrations show that inter-costal spaces are extremely narrow and costae broader than those illustrated by CHOLNOKY and observed here. However, this feature is not considered to be important, for the way of presenting illustrations vary with different authors.

Again, the specimens recorded from the present area, a few ap- 
peared to be somewhat larger in size with more cuneate apices than those recorded by ZANON and CHOLNOKY but they compare well in all the essential features.

58. Pinnularia borealis EHR. v. lonavlensis var. nov. (Pl. 1, fig. 25)

Valvae $60-78.8 \mu$ longae atque $14-16.2 / 16-18.8 \mu$ latae in medio ac ad apices, lineares, marginibus distincte concavis in medio, apicibus late cuneatis, subtruncatis et rotundatis. Raphe tenuis et leniter arcuata, ornata poris centralibus distinctis, unilateraliter inclinatis; fissuris terminalibus distincte curvatis. Area axialis linearis; area centralis magna, rotundata sed unilateraliter dilatata. Striae $4-5$ in $10 \mu$, crassissimae, aliquantum radiales in medio atque in utroque apice convergentes. Typus lectus a H. P. GANDHI ad Lonavla in aquae dulcis, die December-Januari 1945-46, et positus in herbario proprio auctoris sub numero - slide LON-13: 214.

Valves $60-78.8 \mu$ long and $14-16.2 / 16-18.8 \mu$ broad in the middle and at the ends respectively, linear, sides in the middle distinctly concave, ends broadly cuneate, subtruncate and rounded. Raphe thin and weakly arcuate with distinct central pores unilaterally inclined and terminal fissures distinctly curved. Axial area linear; central area large, rounded but unilaterally dilated. Striae $4-5$ in $10 \mu$, very thick, slightly radial in the middle and convergent at the very ends.

This diatom was found in some samples collected from pools in the rivulet, some hill streams and wet clusters of mosses around a rock pool. It occurred in very small number or as a stray form. Not common in the area.

This diatom is considered to be a new variety of $P$. borealis EHR. (HustedT, 1930, Bacil., 326, f. 597), since it very closely compares with it except that the present specimens have well defined concave sides and broadly subcuneate truncately rounded ends. This form also looks like P. lata (BRÉB.) W. SM. v. biconstricta ZANON (ZANON, 1938, Pont. Acad. Cient. Comment., 2: 642, t. 1, f. 30), but Zanon's type has broad and very prominent raphe, very large dimensions and axial and central areas much wider and enlarged, hence it differs.

59. Pinnularia viridis (NITz.) EHR. (Pl. 2, fig. 33)

This species was observed in small number mostly in samples derived from pools in the rivulet, rock pools on the hill inclines and such other places. It occurred in brownish encrustations on partially submerged rocks. Not quite common in the area.

60. Amphora ovalis KüTZ. v. pediculus KüTZ.

This species was commonly found in practically all the samples collected from the area. 
61. Amphora normanii RABH. (P1. 1, fig. 26)

VAN HeurCK, 1896, Treat. Diat., 128, pl. 1, fig. 4; Hustedt, 1930, Bacil., 343, f. 630; Cleve-Euler, 1954, Diat. Schwed. Finn. - III, 97, f. 683.

Frustules 32.5-34 $\mu$ long and $13 \mu$ broad, linear with constricted, broadly produced truncate ends in girdle view. Binding septa numerous. Valves about $6 \mu$ broad, linear-lunate, ends constricted on dorsal side, weakly, obliquely capitate. Raphe thin and straight, almost central with central pores distinct and dorsally bent in a clear central nodule; terminal fissures sharply bent towards the ventral side. Axial area very narrow; central area enlarged. Striae $12-14$ in $10 \mu$, fine and clearly punctate, radial throughout on the dorsal side, middle striae shortened, striae on the ventral side very marginal leaving therefore a broad hyaline area.

This diatom was observed in samples collected from water courses around the hills, water veins from the hill inclines fringed with mosses or liverworts and occasionally in samples from pools in the rivulet. It mostly occurred in small number. Not quite common in the area.

\section{Amphora veneta KüTz.}

This diatom appeared as a common type in samples collected from various pools and ditches. It was generally found mixed up in decaying masses of matter and the like. A widely distributed type in standing waters.

63. Cymbella claasseniae CHol. (P1. 1, fig. 27)

Cholnoky, 1958, Port. Acta biol. (B), 6 (2): 106, t. 1, f. 17-21. Valves $35-50 \mu$ long and $6-7 \mu$ broad, lunate with dorsal side convex and ventral side slightly concave with wide inflation in the middle, ends acutely rounded. Raphe thin, weakly arcuate or straight, less excentric, with central pores closely set and dorsally bent, terminal fissures weakly reflexed towards the dorsal side. Axial area fairly wide, lanceolate; central area not conspicuous. Striae 13-14 in the middle and $16-17$ in $10 \mu$ at the ends, radial in the middle perpendicular to slightly convergent towards the apices.

This species was observed in many samples collected from pools in the rivulet, encrustations on leaky pipes, streams and slowly flowing water courses. It occurred as a frequent diatom in some of the collections, especially from the rivulet.

64. Cymbella sagarensis GANDHI.

This species was mainly observed in samples collected from the rivulet forming encrustations on wet rocks with or without the cover of mosses. 
65. Cymbella sagarensis v. gracilis GANDHI (P1. 1, fig. 28)

This diatom was collected along with the above type but in somewhat greater number. Stray specimens also were observed in samples collected from hill streams and rock pools on hills.

66. Cymbella pusilla GRUN.

This species was observed in good number in samples collected from slowly flowing water courses, water veins on hill inclines and certain other pools.

67. Cymbella amphicephala NAEG.

This species occurred in good number in samples collected from the rivulet, miscellaneous pools and puddles formed under the leaky pipe-line.

68. Cymbella turgida (GREG.) CL.

This diatom was observed in samples collected from pools in the rivulet, miscellaneous ditches, wet partially submerged rocks etc. A common diatom.

69. Cymbella ventricosa KüTz.

This species was collected from various pools having much of rotting vegetable matter, wet soils, waste water courses and puddles formed under the leaky pipes.

70. Cymbella aspera (EHR.) Cl.

This species mainly occurred in samples collected from large pools in the rivulet and hill streams in the form of pale brown encrustations. Not common in the locality.

71. Gomphonema augur EHR.

This species was found in collections made from slowly flowing water courses, leaky water pipes, miscellaneous pools and puddles, clusters of wet mosses around rock pools, etc. It occurred usually in small number but practically in most samples. A fairly distributed type.

72. Gomphonema parvulum (KÜTZ.) GRUN.

This species with its other forms was found quite commonly in samples derived from pools, puddles, ditches, water courses, wet soils and the like. A very common diatom in the area.

73. Gomphonema subventricosum Hustedt (Pl. 2, figs. 34-35)

Husted , 1937-38, Arch. Hydrobiol. Suppl., 15: 440, t. 27, f. $25-26$. 
Valves $47.5-60 \mu$ long and $13-14 \mu$ broad, lanceolate to broadlylanceolate-clavate, more or less inflated in the middle or somewhat angular; apex constricted, broadly produced rounded; base narrower, with concave sides, attenuated and rounded. Raphe somewhat coarse, straight with terminal fissures distinct. Axial area narrowly lanceolate; central area fairly large, unilaterally dilated with an isolated stigma on the opposite side. Striae 10 in the middle upto 12 in $10 \mu$ towards the ends, as a rule irregularly disposed, radial, indistinctly punctate and $1-2$ middle ones abbreviated.

This species was collected in very good number from pools in the rivulet, hill stream, dam-side pavement and other bodies of water. A fairly well distributed diatom in the area.

This species compares very closely with HUSTEDT's type from Java, Bali and Sumatra region, but then local specimens were found to be much larger in size. However, they are considered with the type since they so closely agree in all the essentials especially the setting of the striae. The factor of size alone is not considered to be important.

\section{Gomphonema lanceolatum EHR.}

This type was mostly recorded in small number in good many samples, particularly those collected from pools, water courses and clusters of wet mosses etc.

\section{Gomphonema gracile EHR.}

This species was observed in samples collected from various pools, streams, large ditches in the rivulet and the like. It occurred in varying number in each collection containing slimy stuff or vegetable detritus. A well distributed diatom in the area.

\section{Gomphonema subtile EHR.}

This diatom was particularly found in samples collected from pools in the rivulet, hill streams and pools formed under the leaky pipes. It occurred usually in small number.

\section{Epithemia zebra (EHR.) KÜTz.}

This diatom was observed in samples collected mainly from hill streams and rock pools containing vegetable detritus and sometimes with Chara or Nitella. It occurred as a stray specimen.

\section{Rhopalodia gibba (EHR.) MüLL.}

This species was found to be widely distributed in various pools of hill streams, slowly flowing water courses, rock-pools etc. Sometimes it was noted to be gregarious in encrustations of wet rocks or pool sediments. 
79. Rhopalodia gibba v. ventricosa (EHR.) GRUN.

This diatom found its distribution along with the above type, more commonly observed in samples collected from rock pools of hill streams.

80. Hantzschia amphioxys (EHR.) GRUN.

This species appeared a as common diatom in samples collected from clusters of wet mosses, marginal slime of pools, wet soils, encrustations of leaky pipes etc.

81. Hantzschia amphioxys v. mugadensis GaNDHI (Pl. 1, fig. 29)

GandHI, 1959, Ceylon f. Sci. (Biol. Sci.), 2 (1): 108, pl. 12, f. $26-27$.

Valves $80-98.2 \mu$ long and $10 \mu$ broad, keel punctae $7-8$ in $10 \mu$ and striae about 16 in $10 \mu$, fine but distinctly punctate.

This diatom was collected from certain pools in the rivulet and rock pools on the hills. It occurred only in small number or as a stray form. Not common.

82. Nitzschia tryblionella HaNTz. v. victoriae GRUN.

This diatom mostly occurred in samples collected from the rivulet and hill streams as a characteristic type. Fairly distributed in the locality.

\section{Nitzschia umbilicata HustedT (Pl. 2, fig. 36)}

Hustedt, 1949, Expl. Parc Nat.-Albert Miss. H. Damas, 8: 129, t. 11, f. 65 .

Valves $32.5-36 \mu$ long and $8.7 \mu$ broad, linear, sides rarely slightly concave, ends broadly cuneate constricted produced apiculate. Keel excentric with keel punctae $7-9$ in $10 \mu$, thick, middle of the two somewhat widely set. Striae about 18 in $10 \mu$, coarse and incipiently wavy.

This species appeared in many samples collected from streams, pools, clusters of wet mosses, rock pools with vegetable detritus and the like. It occurred in good number especially in pools having vegetable detritus. A fairly common type.

This diatom appears to be very similar to $N$. calida GRUN., described by Frenguelli (Frengueli, 1923, Bol. Acad. Cienc. Cordoba, 27: 88, t. 7, f. 14-15) and others.

\section{Nitzschia linearis W. SM.}

This species was recorded in samples collected from pools in the rivulet, hill streams, rock pools with vegetable detritus etc. It occurred in varying numbers in several samples. A fairly common diatom in the region. 


\section{Nitzschia amphibia GRUN.}

This species appeared in samples collected from wet soils, pools under leaky pipes, some pools in the rivulet having rotting vegetable matter, etc. It occurred rarely gregariously. A common diatom in the region.

86. Nitzschia frustulum (KÜTz.) GRUN.

This diatom was found to be common in samples collected from wet soils and several pools, puddles and ditches. Sometimes it was found to be gregarious.

87. Nitzschia palea (KüTz.) W. SM.

This species was mostly seen in good number along with two above mentioned types.

88. Nitzschia obtusa W. SM. v. scalpelliformis GRUN.

This diatom was found in samples collected from somewhat polluted pools in the rivulet, dam-side pavement, and such bodies of water which contained much vegetable detritus. Stray specimens also were found in other samples. A diatom from mostly polluted water.

89. Surirella biseriata BRÉB. (P1. 2, fig. 37)

This species was found in samples collected from hill streams, water courses and some pools in the rivulet. It occurred usually in a small number or as a stray type. Not quite common in the area.

90. Surirella tenuissima Hustedt (P1. 1, fig. 38)

This diatom was observed in samples collected from pools in hill streams, slowly flowing water courses and pools formed under leaky pipe line. Not quite common.

91. Surirella linearis W. SM.

This diatom was found in many collections made from pools in the rivulet, hill streams, dam-side pavement and rock pools on hills. It occurred usually in small number mixed up with vegetable detritus. Fairly distributed in the locality.

\section{Surirella robusta EHR.}

This species was especially observed in samples collected from rock pools on the hills, pools in the rivulet and certain streams at foot hills. It occurred in small number or as a stray diatom.

93. Surirella tenera GREG.

This diatom appeared in many samples collected from pools in the 
rivulet, water courses around hills, among cluster of wet mosses and liverworts around rock pools etc. A common diatom in the region.

94. Surirella ovata KüTz. v. pinnata W. SM. (P1. 2, fig. 39)

This diatom was observed in comparatively few samples derived from pools in the rivulet. It occurred in small number or as a stray diatom mostly mixed up in dead vegetable matter or encrustations. $A$ rare diatom in the region.

\section{SUMMARY}

While summing up the result of the present investigation based on comparatively few collections of diatom material from Lonavla area, as they are, it appears that the content of floristic element well compares with that of Bombay and Salsette Islands (Gonzalves \& GANDHI, 1951-53; GANDHI, 1960-61). Several species of diatoms are found common to both the areas having practically the same distributional pattern. However, the number of species recorded from Bombay \& Salsette region, leaving out the brackish water flora, is nearly three times as much as is the case here. It is perhaps due to more thorough exploration of a much larger area compared to Lonavla. Someday, it may be likely that this smaller number may rise up significantly with more complete and expeditious explorations of the region - though the same numerical values may not be captured.

Apart from many common diatoms found in both the regions, Lonavla presents some of its own specific types so far not observed from Bombay and Salsette Islands. The chief among these are: Caloneis pulchra Messik., Cymbella claasseniae CHOL., C. sagarensis GANDHI, C. - v. gracilis GANDHI, Gomphonema subventricosum HusT., Navicula andium FreNG., $N$. cari EHR. v. angusta GRUN., $N$. constans Hust. v. symmetrica Hust., $N$. cuspidata KüTz. v. brevirostrata GANDhI, $N$. dicephala EHR. v. sphaerophora A. CL., $N$. disjuncta Hust., N. gracilis EHR., N. lucidula GRUN, N. mutica KüTz. v. cohnii (HILSE) GrUn., N. radiosa KüTZ., N. subhamulata GrUn., N. terrestris Boye PET., Pinnularia borealis EHR. v. lonavlensis v. nov., P. eburnea (CARLSON) ZANON, P. lonavlensis sp. nov., and $P$. viridis (NITz.) EHR.

Again, the number of diatoms discovered from these hills, the genus Navicula alone appears to be important, whereas genera Cymbella, Nitzschia, Pinnularia, Gomphonema, Surirella and Achnanthes find fair representation. Another noteworthy fact is that genera Pinnularia, Nitzschia, Gomphonema, Eunotia which so prominently figure out in the flora of Bombay and Salsette Islands 
make poor show here - perhaps to give special significance to Naviculas.

In all ninety-four diatoms are recorded from the hilly region of Lonavla representing twenty-two genera. Of these, about 16 are new records for India, one species and one variety is considered to be new to the science.

\section{Plate I.}

Fig. 1-2. Fragilaria ungeriana GRUN. 3. Eunotia pectinalis (KÜTZ.) RABH. v. minor (KÜTZ.) RABH. f. impressa (EHR.) HUST. 4. Caloneis pulchra MEssIK. 5-6. C. bacillum (GRUN.) MERESCH. 7. C. silicula (EHR.) CL. v. minuta Grun. 8. Neidium dubium (EHR.) Cl. v. cuneatum FonT. 9. Diploneis ovalis (HILSE) CL. v. oblongella (NAEG.) CL. 10. Navicula cuspidata KüTZ. v. brevirostrata GANDHI 11. N. disjuncta HUST. 12. N. mutica KÜTZ. v. cohnii (HILsE) GRUN. 13. N. pupula KüTz. v. elliptica Hust. 14. N. subhamulata GRUN. 15. N. terrestris BOYE PeT. 16. N. lucidula GRUN. 17. N. rhynchocephala KüTz. v. amphiceros V. H. 18. $N$. avenacea BRÉB. 19. $N$. radiosa KüTZ. 20. N. gracilis EHR. 21. N. constans Hust. v. symmetrica HusT. 22. $N$. laterostrata Hust. 23. Pinnularia lonavlensis sp. nov. 24. P. eburnea (CARLson) ZanoN 25. P. borealis Ehr. v. lonavlensis v. nov. 26. Amphora normanii RABH. 27. Cymbella claasseniae CHOLNOKY 28. C. sagarensis GANDHI v. gracilis GANDHI 29. Hantzschia amphioxys (EHR.) GRUN. v. mugadensis GANDHI 


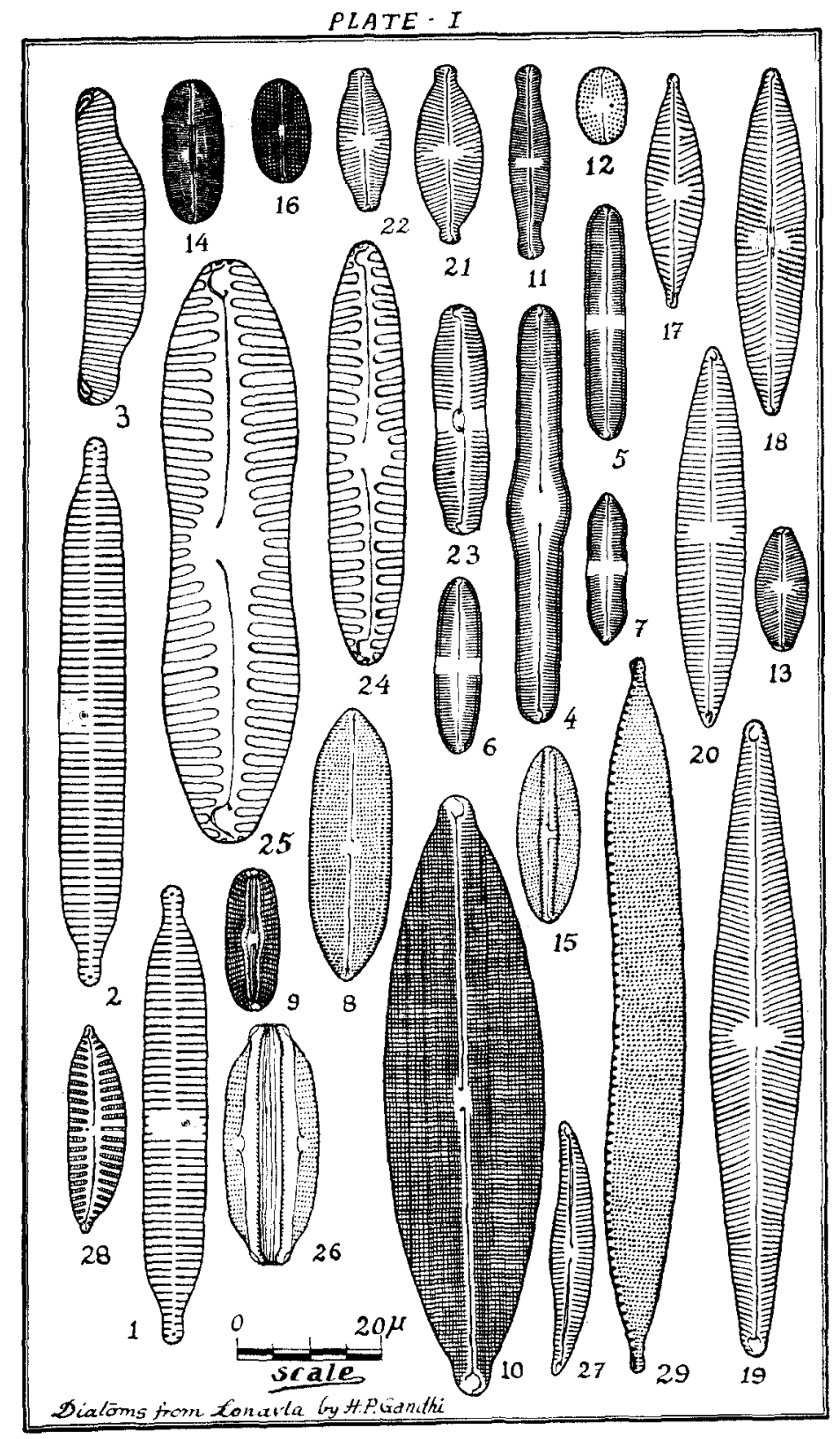




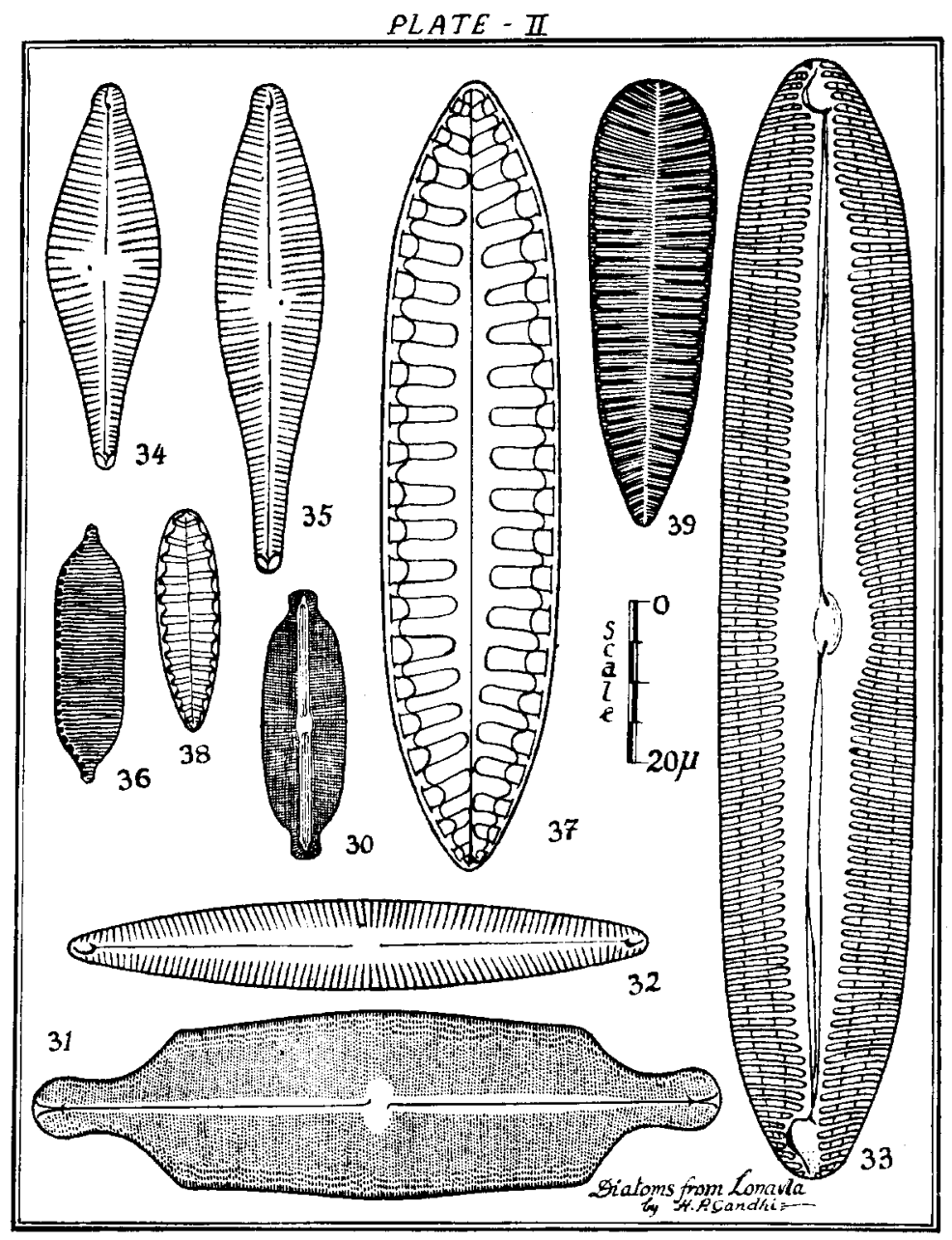

Plate II.

Fig. 30. Frustulia vulgaris THW, v. subcapitata GANDHI 31. Neidium capitellata GANDHI 32. Navicula andium FRENGUELLI 33. Pinnularia viridis (NITZ.) EHR. 34-35. Gomphonema subventricosum Hust. 36. Nitzschia umbilicata HUSTEDT 37. Surirella biseriata BRÉB. 38. S. tenuissima HUSTEDT 39. S. ovata KüTZ. v. pinnata W. SM. 


\section{REFERENCES}

Cholnoky, B. J., - 1956 - Neue und seltene Diatomeen aus Afrika - II. Diatomeen aus dem Tugela-Gebiete in Natal, Osterr. bot. Z., 103: $53-97$.

- 1957 - do - III. Diatomeen aus dem Tugela-Fluss-system hauptsächlich aus den Drakensbergen in Natal, ibid., 104: 25-99.

- $-1958 \mathrm{a}$ - Einige Diatomeen-Assoziationen aus Südwest-Afrika, Senck. Biol., 39 (5-6): 315-326.

-,$-1958 \mathrm{~b}$ - Beiträge zur Kenntnis der Südafrikanischen Diatomeenflora - II. Einige Gewässer im Waterberg-Gebiet, Transvaal, Port. Acta biol., $6(2): 99-160$.

-,-1959 - Neue und seltene Diatomeen aus Afrika - IV. Diatomeen aus der Kaap Provinz, Osterr. bot. Z., $106(1-2): 1-69$.

-, 1960 - Beiträge zur Kenntnis der Diatomeenflora von Natal, Nova Hedwigia, $2(1-2): 1-128$.

Cleve, P. T., - 1894 - Synopsis of the Naviculoid Diatoms, K. Svenska Vet.Akad.Handl., pt. I, 26 (2): 1-194.

Cleve-Euler, A., - 1951-55 - Die Diatomeen von Schweden und Finnland, I, V, II, III, IV, K. Svenska Vet.-Akad. Handl., Fjärde Ser., 2 (1): $1-163 ; 3(3): 1-153 ; 4(1): 1-158 ; 4(5): 1-255 ; 5(4): 1-232$.

FoGED, N., - 1959 - Diatoms from Afghanistan, Biol. Skr. Dan. Vid. Selsk, $11(1): 1-95$.

Frenguelli, J., - 1923 - Contribuciones para la sinopsis de las Diatomeas Argentinas, Bol. Acad. Nac. Cienc. Cordoba, 27: 13-119.

- - 1942 - XVII. Contribución al conocimiento de las Diatomeas Argentinas. Diatomeas del Neuquen (Patagonia), Rev. Museo La Plata, 5 (20): $73-219$.

Funushima, H., - 1954 - Diatomflora of Oze, Sci. Res. Ozegahara Moor, 1954: $602-621$.

GANDHI, H. P., - 1958a - The fresh-water Diatom-flora of the HirebhasgarDam area, Mysore State, $\mathcal{F}$. Indian bot. Soc., 37 (2): 249-265.

__,$-1958 \mathrm{~b}$ - Fresh-water Diatoms from Kolhapur and its immediate environs, F. Bombay Nat. Hist. Soc., 55 (3): 493-511.

- -1957 - The fresh-water Diatoms from Radhanagari - Kolhapur, Ceylon F. Sci. (Biol. Sci), 1 (1): 45-57.

- $-1959 \mathrm{a}-$ Fresh-water Diatoms from Sagar in the Mysore State, $\mathcal{F}$. Indian bot. Soc., 38 (3): 305-331.

- $-1959 \mathrm{~b}$ - Fresh-water Diatomflora of the Panhalgarh Hill-fort in the Kolhapur District, Hydrobiologia, 14 (2): 93-129.

-,$-1959 \mathrm{c}$ - The fresh-water Diatomflora from Mugad, Dharwar District, with some ecological notes, Ceylon F. Sci. (Biol. Sci.), 2 (1): 98-116.

- -1960 - The Diatomflora of the Bombay and Salsette Islands - I, $\mathcal{F}$. Bombay Nat. Hist. Soc., 57 (1): 76-123.

-,-1961 - The Diatomflora of the Bombay and Salsette Islands - II, Nova Hedwigia, 3 (4): 469-505.

GonZal ves, E. A. \& GANDHI, H.P., - 1952-54 - A systematic account of the Diatoms of Bombay and Salsette - I, II, III, F. Indian bot. Soc., 31: $117-151 ; 32: 239-263 ; 33: 338-350$.

Hustedt, F., - 1911 - Beträge zur Algenflora von Bremen. IV. Bacillariaceen aus der Wumme, Abh. naturw. Ver. Bremen, 20: 257-315.

- -1925 - Bacillariales aus Schlesien - II. Nachtrag, Int. Rev. Ges. Hydrobiol. Hydrogr., 13: 345-357. 
-_, - 1930 - Bacillariophyta (Diatomeae), in A. Pascher's Die SüsswasserFlora Mitteleuropas, H. 10, Jena.

- - 1930-60 - Die Kieselalgen Deutschlands, Österreichs und der Schweiz mit Berücksichtigung der übrigen Länder Europas sowie der angrenzenden Meeres-Gebiete, Rabenhorst's Kryptog. Fl. Deutsch. Öster. Schweiz, II, H. 7, Leipzig.

- 1937-38. - Systematische und ökologische Untersuchungen über die Diatomeen-Flora von Java, Bali und Sumatra nach dem Material der deutschen Limnologischen Sunda-Expedition, Arch. Hydrobiol., Suppl., 15: 131-177, 187-295, 393-506, 638-790.

__ - 1949 - Süsswasser-Diatomeen aus dem Albert-Nationalpark in Belgisch-Kongo, Expl. Parc Nat.-Albert Miss. H. Damas, 1935-36, 8: $1-199$.

-,$-1949-50$ - Diatomeen von der Sinai-Halbinsel und aus dem LibanonGebiet, Hydrobiologia, 2: 24-55.

—_, - 1954 - Die Diatomeenflora der Eifelmaare, Arch. Hydrobiol., 48 (4): $451-496$.

_,-1957 - Die Diatomeenflora der Fluss-Systems der Weser im Gebiet der Hansestadt Bremen, Abh. naturw. Ver. Bremen, 34 (3): 181-440.

LUND, J. W. G., - 1946 - Observations on soil Algae - I. The ecology, size and taxonomy of British soil Diatoms, pt. 2, New Phytol., 45 (1): 56-110.

MAYER, A. - 1917 - Beiträge zur Diatomeenflora Bayerns. I. A. Bacillariales aus dem Fichtelgebirge und angrenzenden Gebieten. B. Bacillariales aus dem Bayrischen Walde, Denkschr. Kgl. Bay. Bot. Ges. Regen., 13: $1-97$.

—_- 1919 - Bacillariales aus Reichenhall und Umgebung, Kryptog. Forsch. $1(4): 191-214$.

MCCALL, D., - 1933 - Diatoms (recent and fossil) of the Tay District, F. Linn. Soc. (Bot.) London, 49: 219-308.

MeISTER, F., - 1912 - Die Kieselalgen der Schweiz, Beiträge zur Kryptog. $f$. Schweiz, 4(1): 1-254.

-, 1932 - Kieselalgen aus Asien, Berlin, pp. 1-56, pls. 1-19.

RICH, F., - 1936 - Contribution to our knowledge of the fresh-water Algae of Africa. 12. Some diatoms from the Victoria Falls, Trans. roy. Soc. S. Afr., 24 (III): 207-220.

SchmidT, A., - 1874-1960 - Atlas der Diatomaceen-Kunde, Taf. 1-480, Leipzig.

VAN HeURCK, H., - 1896 - A Treatise on the Diatomaceae (trans. by W. E. Baxter), London.

Venkataraman, G., - 1939 - A systematic account of some South Indian Diatoms, Proc. Indian Acad. Sci., B 10 (6): 293-368.

Zanon, V., - 1938 - Diatomee della regione del Kivu (Congo Belga), Port. Acad. Scient. Comment., 2: 535-668.

_ -1941 - Diatomee dell'Africa occidentale Francese, ibid., 5: 1-60. 